\title{
New records and a new species of Scaphopoda (Mollusca) from the southwestern Atlantic Ocean
}

\author{
Leonardo S. Souza' (1), Carlos Henrique S. Caetano 2 (D), \\ Fabrizio Scarabino ${ }^{3,4}$ (1) \& Paulo Márcio S. Costa ${ }^{1,5}$ (1)
}

\author{
1. Museu Nacional, Universidade Federal do Rio de Janeiro, Departamento de Invertebrados, Malacologia. Quinta da Boa Vista, São Cristóvão, 20940-040 \\ Rio de Janeiro, RJ, Brazil. (leosouza2301@gmail.com) \\ 2. Universidade Federal do Estado do Rio de Janeiro, Departamento de Zoologia, Laboratório de Zoologia de Invertebrados Marinhos. Av. Pasteur, 458 , Urca, 22290-040 \\ Rio de Janeiro, RJ, Brazil. \\ 3. Universidad de la República, Centro Universitario Regional del Este. Ruta 9 intersección Ruta 15, 27000, Rocha, Uruguay. \\ 4. Museo Nacional de Historia Natural. Miguelete 1825, 11800, Montevideo, Uruguay. \\ 5. Fundação Instituto de Pesca do Estado do Rio de Janeiro. Praça Fonseca Ramos s/n, Centro, 24030-020 Niterói, RJ, Brazil.
}

Received 19 May 2020

Accepted 10 August 2020

Published 09 September 2020

DOI $10.1590 / 1678-4766 e 2020023$

\begin{abstract}
The geographical distribution of Bathoxiphus ensiculus (Jeffreys, 1877) and Cadulus platensis Henderson, 1920 is greatly extended based on new records, the former being registered for the first time in the southwestern Atlantic. The type materials of both species are figured and an updated diagnosis of Bathoxiphus Pilsbry \& Sharp, 1897 is presented. A new deep-sea species of Cadulus is described, Cadulus victori sp. nov., known from only empty shells collected in the Northeast Brazil (off Alagoas and Bahia states) and distinguished from his congeners mainly by the strongly inflated shell, general outline and dimensions. The present study reinforces that although recent taxonomic revisions have been performed on the Scaphopoda from the southwestern Atlantic, there are still unknown or unrecorded species in museum collections, mostly from poorly sampled areas, especially in the deep sea.
\end{abstract}

KEYWORDS. Gadilidae; Entalinidae; Bathoxiphinae; Bathoxiphus; Cadulus.

The class Scaphopoda is composed by exclusively marine species and is mainly characterized by an external tubular shell, usually curved, and opened at both ends (REYNOLDS, 2002). Scaphopods have a world-wide distribution, live infaunally, occur from intertidal to abyssal depths and most species feed primarily on foraminiferans (REYNOLDS, 2002; Sigwart et al., 2017).

The Scaphopoda is one of the smallest molluscan classes with estimates of about 580 extant valid species (Rosenberg, 2014; MolluscaBase, 2018b). Steiner \& KАВAT (2004: fig. 1) illustrated a graphic with the number of species names introduced per decade (between 1750-2004), pointing out that the greatest peaks were at the end of the $19^{\text {th }}$ and $20^{\text {th }}$ centuries. A latter peak is mainly attributed to the studies of Scarabino (1995) and Lamprell \& Healy (1998), which are major revisions made on the species found in the Indian and Pacific oceans. In the Atlantic, the major taxonomic revision of Scaphopoda was conducted by HENDERSON (1920), and more recently other contributions were performed with an emphasis on the southwestern region (i.e., Scarabino, 1986a,b; Absalão \& de Paula, 2004; CAetano \&ABsalão, 2005; CAETANo et al., 2006, 2007, 2010; Scarabino \& Caetano, 2008; Caetano \& Santos, 2010; Silva-Filho et al., 2010, 2012, 2016; SCARABino \&
Scarabino, 2011; Scarabino et al., 2011; Souza et al., 2013).

In the last five years, descriptions of new species of Scaphopoda were rare, i.e., only four extant species were described. These newly described scaphopods occur in the Mediterranean, Indian and Pacific Oceans (CAPROTTI, 2015; SAHLMANN \& VAN DER BeEK, 2016; SAHLMANN \& Wise, 2016; Sahlmann et al., 2016). Despite the recent efforts in reviewing the Scaphopoda from the southwestern Atlantic, examination of samples from bathyal depths off Brazil continues to reveal new records and unknown species. In the present study we report new occurrences of Cadulus platensis Henderson, 1920 and Bathoxiphus ensiculus (Jeffreys, 1877), and describe a new species of Cadulus Philippi, 1844.

\section{MATERIALS AND METHODS}

The material examined is housed in different malacological collections and consists exclusively of empty shells. Most samples from Brazil were collected by two different projects: 1) MARSEAL: "Caracterização Ambiental da Bacia de Sergipe-Alagoas" [Environmental Characterization of Sergipe and Alagoas Basin], between 5 and $4300 \mathrm{~m}$, coordinated by PETROBRAS/CENPES; 2) "Crostas Cobaltíferas da Elevação do Rio Grande" 
[Cobaltiferous crusts from Rio Grande Rise], between 2010 and 2012, coordinated by the Geological Survey of Brazil, CPRM (PROERG). The remaining material was collected by other smaller projects.

The taxonomic identifications were based on comparisons with type material and original descriptions and illustrations. The number inside the brackets in the examined material indicates the number of shells present in each lot. Descriptive terms of the shell morphology are those of SCARABINO (1995: fig. 1), except the body orientation that was recently reviewed by SigwarT et al. (2017: fig. 2), in which the apertures are named as ventral (formerly anterior) and dorsal (formerly posterior), the latter also known as the apex of the shell. The convex part of the shell is the posterior region (formerly ventral) and the concave part is the anterior region (formerly dorsal).

Morphometric data of the shell were obtained based on direct examination of specimens and on images, added by information gathered from the literature. The measurements follow CAETANO et al. (2010) and are here described as: L, total length; Max, maximum diameter; Dmax, distance of the maximum diameter to the ventral aperture; Arc, height of the point of maximum curvature; Larc, distance of the point of maximum curvature to the dorsal aperture; $\mathrm{Hd}$, height of dorsal aperture; $\mathrm{Wd}$, width of dorsal aperture; Hv, height of ventral aperture; $\mathrm{Wv}$, width of ventral aperture. Ratios based on previous measurements were also calculated following CAETANO et al. (2010): L/Max; Hd/Wd; Hv/Wv.

Institutional abbreviations used herein: MCZ: Museum of Comparative Zoology, Harvard University, Cambridge, Massachussetts, USA; MNHN-IM: Muséum national d'Histoire naturelle, Paris, France; MNRJ: Museu Nacional, Universidade Federal do Rio de Janeiro, Rio de Janeiro, Brazil; NHMUK: Natural History Museum of the United Kingdom, London, England, United Kingdom; USNM: Smithsonian Institution's National Museum of Natural History, Washington DC, USA; CZUFS SCA: Universidade Federal de Sergipe, São Cristóvão, Sergipe, Brazil.

Due to the fire in the "Museu Nacional" (Zamudio et al., 2018), some vouchers housed or on loan at this collection were destroyed and are here indicated with a dagger $(\dagger)$ aside the catalog number.

\section{RESULTS}

\section{Entalinidae Bathoxiphinae}

Diagnosis. Shell narrow, slender, evenly expanding, slightly curved when adult, sometimes with keel, compressed laterally, elliptic or oval in section, upper $2 / 3$ of shell very thick. Longitudinal sculpture poorly developed, transverse sculpture represented by oblique growth lines and sometimes by ring-like bulges. Apex with wide anterior (formerly dorsal, concave side) groove or cut diagonally towards to posterior (formerly ventral, convex side) side. Epipodial appendages less than $1 / 3$ of channel when foot screwed. Pavilion and subpavilion of the same length. Central radular teeth with spoon-like anterior plates with three denticles facing up. Lateral teeth elongated with large tips bent backwards and three median cusps, M1 small, rarely absent (adapted from Chistikov, 1983).

Remarks. Bathoxiphinae was introduced as a subfamily of Entalinidae and comprises three genera: Bathoxiphus Pilsbry \& Sharp, 1897 (four species), Rhomboxiphus Chistikov, 1983 (three species) and Solenoxiphus Chistikov, 1983 (monotypic) (STEINER \& Kabat, 2001; MollusCABASE, 2018a), and only the former is known from the Atlantic. As the original diagnosis of the subfamily is in Russian, a translated version is presented here for wider dissemination.

\section{Bathoxiphus Pilsbry \& Sharp, 1897}

Type species. Dentalium ensiculus Jeffreys, 1877, by subsequent designation (BoISSEvaIN, 1906:48).

Diagnosis. Shell small to medium in size, strongly arched, solid, polished, usually smooth or with thin longitudinal sculpture. Apex truncated, lumen circular. Section oval, strongly laterally compressed. Radula with high rachidian tooth, anterior margin simple, rounded with latter half folded inward; lateral teeth present two pointed primary cusps and 5 to 6 subequal secondary cusps; marginal teeth slightly curved (adapted from SCARABINO, 1995; SCARABINO \& SCARABINO, 2010).

Remarks. Aside from the type species, three other are currently included in the genus: Bathoxiphus soyomaruae Okutani, 1964 (bathyal and abyssal, Japan, New Caledonia and the Indian Ocean), Bathoxiphus inexpectatus Scarabino, 1995 (bathyal, New Caledonia, Pacific Ocean) and Bathoxiphus kathieae Scarabino \& Scarabino, 2010 (bathyal, Solomon Islands, Pacific Ocean) (Chistikov, 1983; SCARABino, 1995, 2008; Scarabino \& SCARABIno, 2010).

The species of Bathoxiphus usually have smooth shells, but $B$. kathieae presents longitudinal sculpture of thin ribs which is the main difference from his congeners. Despite the different sculpture, $B$. kathieae has the conspicuous radular morphology shared by all species of the genus. The diagnosis of the genus is updated here.

\section{Bathoxiphus ensiculus (Jeffreys, 1877)}

(Figs 1-18)

Dentalium ensiculus JEFFREYS, 1877:154

Dentalium sigsbeanum DALL, 1881:38.

Dentalium ensiculus-JEFFrEYs, 1882:660, pl. 49, fig. 4; VERRILL, 1885:432; Watson, 1886 (not 1885 as cited by HeNDERSON 1920):12, pl. 2, fig. 2; DALL, 1889:428, pl. 27, fig. 12; 1890:294.

Dentalium (Bathoxiphus) ensiculus - PILsBry \& Sharp,1897:121, pl. 7, figs. 7-10; DAll, 1927:17; EMERSON, 1952:6; Аввотт, 1974:387, fig. 4526.

Bathoxiphus ensiculus - CHISTIKov,1983:183, pl. 1, figs. 1-5, pl. 4, fig. 5; Steiner \& KabAT, 2004:588; Gofas et al., 2017:8. 


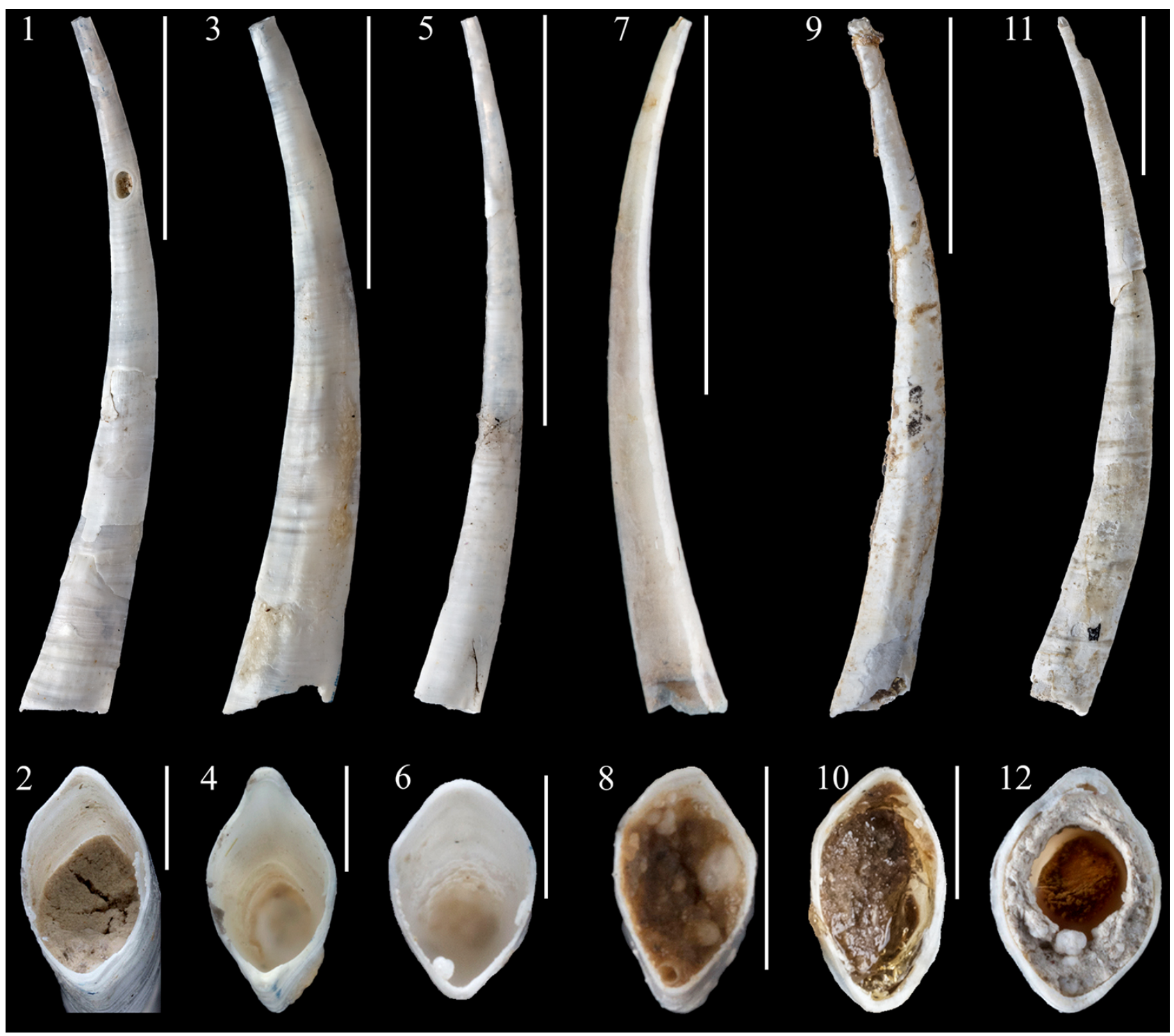

Figs 1-12. Bathoxiphus ensiculus (Jeffreys, 1877). 1-6, syntypes (NHMUK 1877.11.28.56): 1, 2: same shell; 3, 4: same shell; 5, 6: same shell; 7-12, syntypes (NHMUK 1885.11.5.1344-46): 7, 8: same shell; 9, 10: same shell; 11, 12: same shell. 1, 3, 5, 7, 9, 11, entire shell, lateral view; 2, 4, 6, 8, 10, 12 , detail of ventral aperture. Scale bars: $1,3,5,7,9,11=5 \mathrm{~mm} ; 2,4,8,10,12=1 \mathrm{~mm} ; 6=0.5 \mathrm{~mm}$. Credits: K. Webb (NHMUK photographic unit).

Type material. Syntypes: NORTH ATLANTIC: Porcupine expedition unknown sta. (NHMUK 1885.11.5.134446,3 shells); Valorous expedition, $2652 \mathrm{~m}$ [originally as " 1450 fms"](NHMUK 1877.11.28.56a-c,3 shells); Valorous exp. sta. $12,56^{\circ} 11^{\prime} \mathrm{N} 37^{\circ} 41^{\prime} \mathrm{W}, 2652 \mathrm{~m}$ [originally as " $1450 \mathrm{fms}$ "] (USNM 176126, 16 shells); Valorous exp.sta. 16, $55^{\circ} 10^{\prime} \mathrm{N}$ $15^{\circ} 58^{\prime} \mathrm{W}, 3264 \mathrm{~m}$ [originally as " $1785 \mathrm{fms}$ "](USNM 176131, 1 shell); Porcupine exp. 1869 sta. $19,54^{\circ} 53^{\prime} \mathrm{N} 10^{\circ} 56^{\prime} \mathrm{W}$, 2487 m [originally as " $1360 \mathrm{fms"](USNM} \mathrm{176127,1} \mathrm{shell);}$ Porcupine exp. 1869 sta. $42,49^{\circ} 12^{\prime} \mathrm{N} 12^{\circ} 52^{\prime} \mathrm{W}, 1576 \mathrm{~m}$ [originally as " 862 fms"](USNM 176128, 1 shell]; Porcupine exp. 1870 sta. $17,39^{\circ} 42^{\prime} \mathrm{N} 9^{\circ} 43^{\prime} \mathrm{W}, 2003 \mathrm{~m}$ [originally as "1095 fms"](USNM 176129, 5 shells); Porcupine exp. 1870 sta. $16,39^{\circ} 55^{\prime} \mathrm{N} 9^{\circ} 56^{\prime} \mathrm{W}, 1818 \mathrm{~m}$ [originally as “994 fms”] (USNM 176130, 9 shells).

Type locality. A holotype, as well as a type locality, were not designated by JEFFREYs (1877). However, based on the list of examined syntypes, it can be assigned that the original description was based on samples collected from many places in the Northeast Atlantic, between 1576 and 3264 $\mathrm{m}$. As we have not been able to examine all the syntypes, a precise type locality could not be determined.

Material examined. Syntypes NHMUK 1885.11.5.1344-46 and NHMUK 1877.11.28.56a-c. BRAZIL, Rio de Janeiro: Santos Basin, Alto de Cabo Frio sta. 9, 24¹4'56"'S 41³2'11"W, 1900 m, coll. 2018 (MNRJ 23600, 1 shell); Santos Basin, Gato do Mato sta. 1, 2501'14"S 4300'56”W, 2050 m, coll. 2018 (MNRJ 23601, 1 shell); São Paulo: Santos Basin, Carcará East sta. 1, 2523’28’S 435' $40^{\prime}$ 'W, $2100 \mathrm{~m}$, coll. 16-22/i/2019 (MNRJ 60839, 2 shells); Santos Basin, Carcará East sta. 3, 2523'32"'S 4357'45”'W, 2100 m, coll. 16-22/i/2019 (MNRJ 60826, 1 shell); Santos Basin, Carcará East sta. 4, 2523'23”'S 43 ${ }^{\circ} 57^{\prime} 45$ ”'W, 2100 m, coll. 16-22/i/2019 (MNRJ 60823, 
2 shells); Santos Basin, Carcará East sta. 5, 2523'15”S 4357'29"W, $2100 \mathrm{~m}$, coll. 16-22/i/2019 (MNRJ 60821, 1 shell); Santos Basin, Carcará East sta. 10, 25²4’04”S 4358'16”'W, 2100 m, coll. 16-22/i/2019 (MNRJ 60832, 1 shell).

Distribution. Western Atlantic: Greenland; USA: Massachusetts, Delaware, Georgia, Florida (DALL, 1890; Henderson, 1920); Mexico: Yucatan Strait (DALl, 1881); Cuba (Henderson, 1920); Puerto Rico (Emerson, 1952); Anguilla: Sombrero Island (Watson, 1886); St. Barts; Barbados; St. Vincent and Grenadines (Henderson, 1920); Brazil: Rio de Janeiro, São Paulo (this study). Eastern Atlantic: Ireland; Portugal (JeFFreys, 1877); Spain (GofAS et al., 2017); Namibia (?) (SteIner \& KABAT, 2004). Empty shells from $353 \mathrm{~m}$ to $3264 \mathrm{~m}$.

Remarks. The type material of $B$. ensiculus consists of several syntypes housed in the collections of NHMUK (Figs 1-12) and USNM. WARÉN (1980) and STEINER \& KABAT (2004) did not locate the syntypes NHMUK 1877.11.28.56a$\mathrm{c}$, but the three shells were found in the present study (Tom White pers. commun.) and are figured here (Figs 1-6). The syntypes from the USNM were not examined in the present study and a lectotype designation is postponed until it is possible to examine the complete type series of B. ensiculus.

Bathoxiphus ensiculus was originally described from several localities in the Northeast Atlantic (JEFFREYS, 1877) and later VerRILL (1885) recorded for the first time this species from the Northwest Atlantic. It is currently known from both sides of the North Atlantic, with a restricted distribution to the northern hemisphere in the western Atlantic, and in the eastern side, it is reported from Ireland (northern hemisphere) to Namibia (southern hemisphere) by SteINER \& KABAT (2004). The latter authors did not report the source of the record from the southeastern Atlantic and the occurrence of this species in this region needs confirmation.

In the present study, B. ensiculus is recorded in the southwestern Atlantic for the first time. The empty shells collected in the Southeast coast of Brazil at about $2100 \mathrm{~m}$ fit the morphology of the syntypes examined (Figs 1-12) in having an elongated, strongly arched, laterally compressed shell, showing an over half apical notch in the anterior side of the apex (Figs 13-18). The shells from Brazil are slightly smaller than the largest syntypes of $B$. ensiculus, but reach a strong curvature like them (Tab.I).

\section{Gadilidae}

\section{Cadulus Philippi, 1844}

Type species. Dentalium ovulum Philippi,1844, by monotypy.

\section{Diagnosis. See CaEtano et al.(2006).}

Cadulus platensis Henderson, 1920

(Figs 19-27)

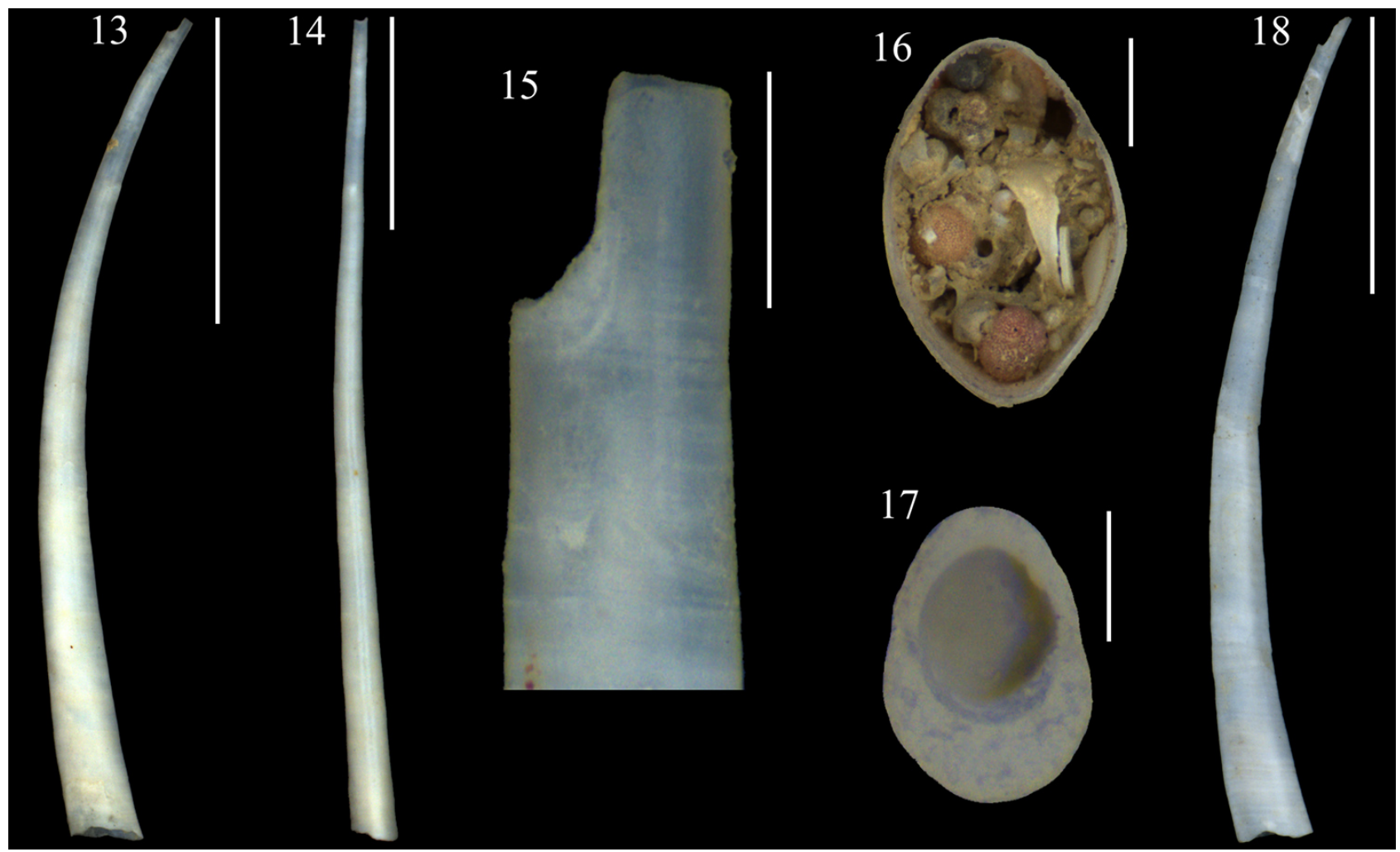

Figs 13-18. Bathoxiphus ensiculus (Jeffreys, 1877). 13-17, MNRJ 60821, same shell; 18, MNRJ 60823. 13, 18, entire shell, lateral view; 14, entire shell, anterior view. 15 , detail of the apex; 16 , detail of ventral aperture; 17 , detail of dorsal aperture. Scale bars: $13,14,18=5 \mathrm{~mm} ; 15,16=0.5 \mathrm{~mm} ; 17=0.2 \mathrm{~mm}$. 
Tab. I. Morphometric data (in millimeters, except ratios) of studied scaphopods. The horizontal bars (-) indicates unavailable data. Abbreviations: Arc: height of curvature; Dmax: distance of the maximum diameter to the ventral aperture; Hd: height of dorsal aperture; Hv: height of ventral aperture; L: length; Larc: distance of the point of maximum curvature to the dorsal aperture; Max: maximum diameter; SD: standard deviation; Wd: width of dorsal aperture; Wv: width of ventral aperture. Source of data: 1: Present study; 2: Dall (1881); 3: Henderson (1920); 4: NiCKLÈs (1979).

\begin{tabular}{|c|c|c|c|c|c|c|c|c|c|c|c|c|c|c|}
\hline Species & $\begin{array}{l}\text { Type material / } \\
\text { Vouchers }\end{array}$ & $\mathrm{L}$ & Max & $\mathrm{L} / \mathrm{Max}$ & Dmax & Arc & Larc & $\mathrm{Hd}$ & $\mathrm{Wd}$ & $\begin{array}{l}\mathrm{Hd} / \\
\mathrm{Wd}\end{array}$ & $\mathrm{Hv}$ & Wv & $\begin{array}{l}\mathrm{Hv} / \\
\mathrm{Wv}\end{array}$ & Source \\
\hline \multirow{9}{*}{ B. ensiculus } & $\begin{array}{c}\text { NHMUK } \\
1877.11 .18 .56 \mathrm{a}\end{array}$ & 15.6 & - & 9.6 & - & 0.9 & 6.0 & - & - & - & 1.9 & 1.2 & 1.6 & 1 \\
\hline & $\begin{array}{c}\text { NHMUK } \\
1877.11 .18 .56 \mathrm{~b}\end{array}$ & 12.8 & - & 10.2 & - & 0.8 & 5.1 & - & - & - & 2.0 & 1.2 & 1.7 & 1 \\
\hline & $\begin{array}{c}\text { NHMUK } \\
1877.11 .18 .56 \mathrm{c}\end{array}$ & 8.5 & - & 15.5 & - & 0.3 & 2.7 & - & - & - & 0.9 & 0.6 & 1.5 & 1 \\
\hline & $\begin{array}{c}\text { NHMUK } \\
1885.11 .5 .1344\end{array}$ & 9.2 & - & 13.6 & - & 0.6 & 3.4 & - & - & - & 1.1 & 0.7 & 1.6 & 1 \\
\hline & $\begin{array}{c}\text { NHMUK } \\
1885.11 .5 .1345\end{array}$ & 14.8 & - & 9.1 & - & 0.9 & 5.3 & - & - & - & 1.9 & 1.0 & 1.8 & 1 \\
\hline & $\begin{array}{c}\text { NHMUK } \\
1885.11 .5 .1346\end{array}$ & 22.0 & - & 6.4 & - & 1.7 & 8.9 & - & - & - & 2.4 & 1.7 & 1.4 & 1 \\
\hline & USNM 95347 & 19.0 & - & 12.7 & - & 1.8 & - & - & - & - & - & - & - & 3 \\
\hline & MNRJ 60821 & 17.3 & - & 11.2 & - & 1.5 & 6.8 & 0.5 & 0.3 & 1.5 & 1.7 & 1.1 & 1.5 & 1 \\
\hline & MNRJ 60823 & 12.5 & - & 12.7 & - & 1.2 & 5.8 & 0.4 & 0.3 & 1.4 & 1.3 & 0.9 & 1.5 & 1 \\
\hline Mean & & 14.6 & - & 11.2 & - & 1.1 & 5.5 & 0.4 & 0.3 & 1.4 & 1.7 & 1.0 & 1.6 & \\
\hline$\pm \mathrm{SD}$ & & 4.4 & - & 2.7 & - & 0.5 & 1.9 & 0.1 & 0 & 0 & 0.5 & 0.3 & 0.1 & \\
\hline C. cucurbitus & MCZ 7750 & 4,0 & 1.25 & 3.2 & - & - & - & - & 0.4 & - & - & 0.6 & - & 2 \\
\hline \multirow{2}{*}{ C. exiguus } & NHMUK 1887.2.9.94 & 1.9 & 0.9 & 2.2 & 0.9 & - & - & - & - & - & - & - & - & 1 \\
\hline & NHMUK 1887.2.9.94 & 1.8 & 0.9 & 2.1 & 1.0 & - & - & - & - & - & - & - & - & 1 \\
\hline Mean & & 1.8 & 0.9 & 2.1 & 1.0 & - & - & - & - & - & - & - & - & \\
\hline$\pm \mathrm{SD}$ & & 0 & 0 & 0 & 0 & - & - & - & - & - & - & - & - & \\
\hline \multirow[b]{2}{*}{ C. gibbus } & USNM 172858 & 2.4 & 0.9 & 2.6 & 1.2 & - & - & - & - & - & - & - & - & 1 \\
\hline & $\begin{array}{c}\text { NHMUK } \\
1885.11 .5 .1287\end{array}$ & 2.4 & 1.1 & 2.3 & 1.2 & - & - & - & - & - & - & - & - & 1 \\
\hline Mean & & 2.4 & 1.0 & 2.4 & 1.2 & - & - & - & - & - & - & - & - & \\
\hline$\pm \mathrm{SD}$ & & 0 & 0.1 & 0.2 & 0 & - & - & - & - & - & - & - & - & \\
\hline \multirow{3}{*}{ C. platensis } & USNM 887476 & 5.4 & 1.8 & 3.0 & 2.7 & - & - & 0.8 & 0.8 & 1.1 & 0.5 & 0.6 & 0.9 & 1 \\
\hline & MNRJ 27204 & 5.4 & 1.7 & 3.2 & 2.7 & - & - & 0.9 & 0.8 & 1.2 & 0.6 & 0.6 & 0.9 & 1 \\
\hline & MNRJ 27204 & 3.9 & 1.5 & 4.5 & 1.9 & - & - & 0.7 & 0.8 & 0.9 & 0.5 & 0.5 & 1.0 & 1 \\
\hline Mean & & 4.9 & 1.6 & 3.6 & 2.4 & - & - & 0.8 & 0.8 & 1.1 & 0.5 & 0.6 & 0.9 & \\
\hline$\pm \mathrm{SD}$ & & 0.8 & 0.2 & 0.8 & 0.4 & - & - & 0.1 & 0 & 0.1 & 0.1 & 0.1 & 0.1 & \\
\hline C. rossoi & $\begin{array}{c}\text { MNHN- } \\
\text { IM-2000-30323 }\end{array}$ & 1.8 & 0.9 & 2.1 & 0.9 & - & - & - & - & - & - & - & - & 4 \\
\hline \multirow{4}{*}{ C. tumidosus } & USNM 169502 & 5.5 & 1.9 & 2.9 & 2.9 & - & - & - & - & - & - & - & - & 1 \\
\hline & USNM 169502 & 5.2 & 1.5 & 3.4 & 2.8 & - & - & - & - & - & - & - & - & 1 \\
\hline & USNM 169502 & 4.8 & 1.9 & 2.6 & 2.4 & - & - & - & - & - & - & - & - & 1 \\
\hline & USNM 169502 & 5.1 & 1.7 & 3.1 & 2.7 & - & - & - & - & - & - & - & - & 1 \\
\hline Mean & & 5.2 & 1.7 & 3.0 & 2.7 & - & - & - & - & - & - & - & - & \\
\hline$\pm \mathrm{SD}$ & & 0.3 & 0.2 & 0.4 & 0.2 & - & - & - & - & - & - & - & - & \\
\hline \multirow{2}{*}{ C. victori } & CZUFS SCA-00005 & 4.4 & 1.9 & 2.3 & 2.2 & - & - & 0.6 & 0.7 & 0.9 & 0.9 & 0.8 & 1.1 & 1 \\
\hline & MNRJ 34466 & 5.0 & 2.1 & 2.4 & 2.5 & - & - & 0.7 & 0.7 & 0.9 & 1.0 & 1.0 & 1.1 & 1 \\
\hline Mean & & 4.7 & 2.0 & 2.3 & 2.3 & - & - & 0.6 & 0.7 & 0.9 & 0.9 & 0.9 & 1.1 & \\
\hline$\pm \mathrm{SD}$ & & 0.4 & 0.1 & 0.1 & 0.2 & - & - & 0 & 0.1 & 0 & 0.1 & $0 .$. & 0 & \\
\hline
\end{tabular}


Cadulus platensis Henderson, 1920:147, pl. 20, fig. 14

Cadulus platensis-DALl, 1927:19; SCARABINO,1970:41; 1975:182, pl.

58, fig. 884 [reproduced from original illustration]; 1985:201, pl. 73, fig. 1029 [reproduced from original illustration]; 1994:309, pl. 107, fig. 1517; Steiner \& Kabat, 2001:440; 2004:631; Scarabino, 2003:193; CAETANO \& SCARABINO,2009:455 [fig. at the top of the page, not fig. 1287].

Type material. Holotype (USNM 887476, 1 shell). Paratypes: from type locality, USNM 330845 [2 shells]; USA, Florida, off Fernandina, USBF sta. $2415,30^{\circ} 44^{\prime} \mathrm{N}$ $79^{\circ} 26^{\prime} \mathrm{W}, 805 \mathrm{~m}$ [440 fms], coll. Steamer Albatross, 01/ iv/1885 (USNM 108279, 2 shells); Georgia, off Georgia, USBF sta. 2668,3058'30'N 79॰38'30’'W, 538 m [294 fms], coll. Steamer Albatross, 05/v/1886 (USNM 108172, 7 shells; AMNH 148340, 1 shell); BRAZIL, Ceará, USBF sta.
2760, $12^{\circ} 07^{\prime} \mathrm{S} 37^{\circ} 17^{\prime} \mathrm{W}, 1864 \mathrm{~m}$ [1019 fms], coll. Steamer Albatross, 18/xii/1887(USNM 95447, 1 shell).

Type locality. Originally stated as ARGENTINA, Buenos Aires, off Río de la Plata, USBF sta. 2764, 36 42'S $56^{\circ} 23^{\prime} \mathrm{W}, 21 \mathrm{~m}$ [11.5 fms]. Corrected to: BRAZIL, Rio de Janeiro, USBF sta. $2763,24^{\circ} 17^{\prime} \mathrm{S} 42^{\circ} 48^{\prime} \mathrm{W}, 1228 \mathrm{~m}$ [671 $\mathrm{fms}$ (SCARABINO, 2003: footnote 3; see Remarks).

Material examined. Type material. BRAZIL: São Paulo: off Santos (3059 m), coll. R/V Wladimir Besnard, 1975 (MORG 20181, 1 shell); off Santos, 235’’S 46¹9’W, $400 \mathrm{~m}$, coll. R/V Wladimir Besnard (MZSP $119362 \dagger, 8$ shells); Rio Grande do Sul: Rio Grande Rise, ERG sta. 001, 2953'24'S 36³9'21'W, 1439-1689 m, coll. Supply Boat Astro Garoupa, 07/vi/2011 (MNRJ 27204†, 2 shells).

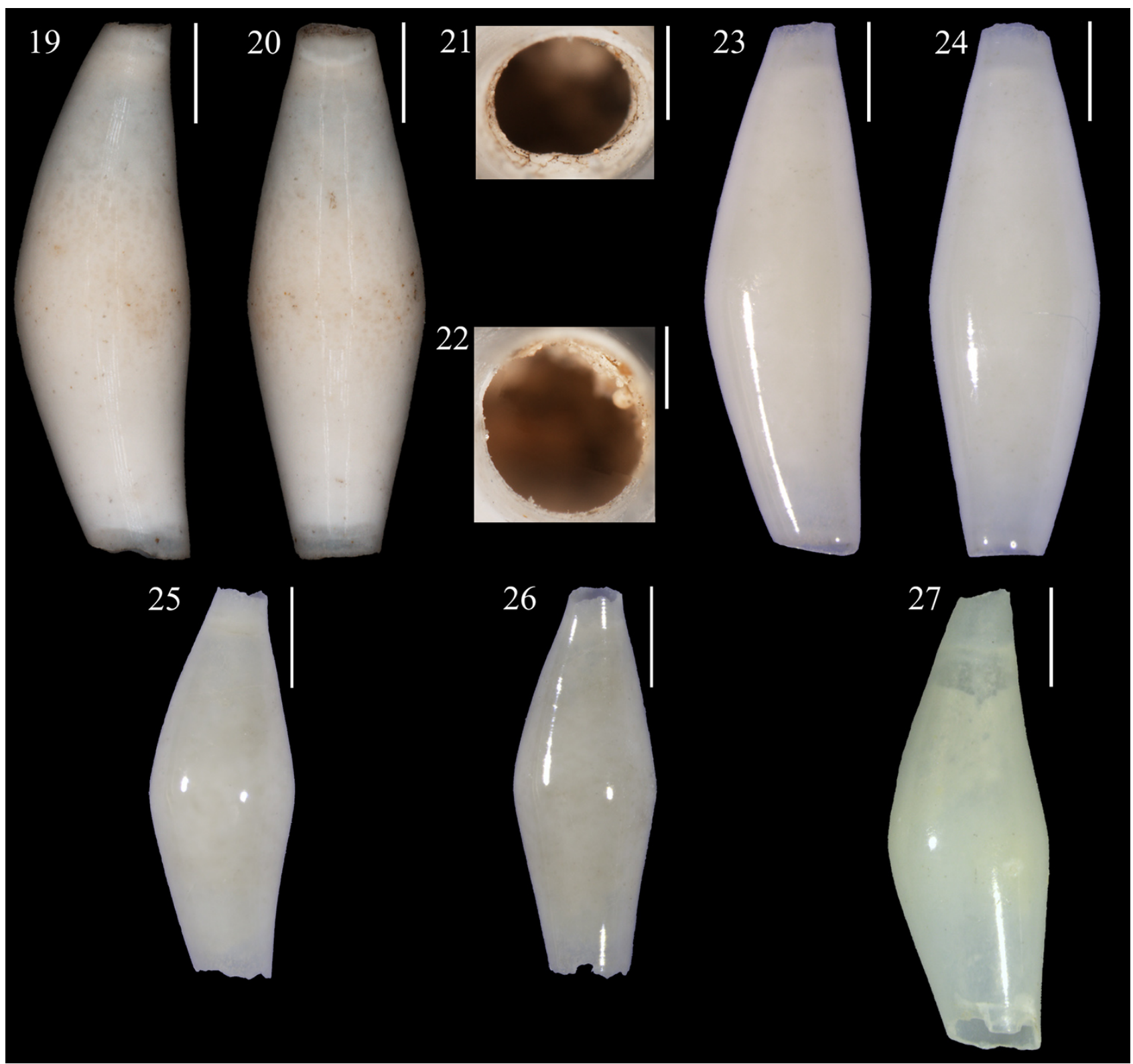

Figs 19-27. Cadulus platensis Henderson, 1920. 19-22, holotype (USNM 887476); 23-26, MNRJ 27204: 23, 24, same shell; 25, 26, same shell; 27, MZSP 119362.19, 23, 25, 27, entire shell, lateral view; 20, 24, 26, entire shell, anterior view; 21, detail of dorsal aperture; 24, detail of ventral aperture. Scale bars: $19,20,23-27=1 \mathrm{~mm} ; 21,22=0.4 \mathrm{~mm}$. 
Distribution. USA: Georgia, Florida; Brazil: Ceará (Henderson, 1920), São Paulo (Rios, 1994; Caetano \& Scarabino, 2009), Rio Grande do Sul (Rio Grande Rise) (this study).

Remarks. The holotype of $C$. platensis (USNM 887476) (Figs 19-22) and two other paratypes (USNM 330845) were supposedly collected off "Río de la Plata", Argentina (USBF sta. 2764), a shallow locality, while the other records were in bathyal depths. HENDERSON (1920:15) himself doubted the reliability of the record: "A false note is touched in an 11-fathom station off Rio de la Plata quoted four times in our table, and in each instance for deep-water species of other stations. I feel quite sure that some error has been made in recording this station (No. 2714) [sic, misquote for 2764] by the United States Fish Commission". The same doubt was raised by QuINN (1979:14-15; 1983:358-361) for records of some Vetigastropoda.

TownSEND (1901) reported that the same sampling equipment was used in the USBF sta. 2763 and sta. 2764, which were sequentially sampled and may lead to a contamination of the samples. Based on these doubts and facts, Scarabino (2003:193, footnote 3) corrected the type locality of $C$. platensis to off Rio de Janeiro, Brazil, at the USBF sta. 2763. Furthermore, the latter author also supported his decision based on the presence of this species in samples collected off Rio de Janeiro during the MD55 expedition. There are similar cases of gastropods collected from the same locality, as Carenzia trispinosa (Watson, 1879) and Pendroma perplexum Dall, 1927. Carenzia trispinosa was recorded by QUINN (1979) at the USBF sta. 2764, and is also known from samples collected by the MD55 expedition off Rio de Janeiro (SALVADOR et al., 2014). However, in the case of this gastropod, SALVADOR et al. (2014) did not discuss about the presence of the species in the USBF sta. 2764 and considered the distribution of Carenzia trispinosa in Argentina, although not including the shallow record in the bathymetric range of the species. Pendroma perplexum is also known from samples of the MD55 (F. Scarabino, pers. obs.) and belongs to a family constituted by bathyal species (Pendromidae; WARÉN 1991). These cases reinforce SCARABINO's (2003) hypothesis about the correct type locality of $C$. platensis.

Based on the explanations above, the southernmost record of C. platensisis currently off São Paulo state, Brazil (Scarabino, 1994; Caetano \& Scarabino, 2009). Caetano \& SCARABINO (2009:455) presented confusing figures and the order of the images are corrected here to avoid confusions: from the top of the page, the species figured are Cadulus platensis, Gadila braziliensis (Henderson, 1920), Gadila dominguensis (d'Orbigny, 1842) and Cadulus parvus Henderson, 1920.

In the present study, we report a new record of $C$. platensis in the Rio Grande Rise, South Atlantic, extending the geographic distribution of the species southward. The two shells collected there (Figs 23-26) closely resemble the morphology of the holotype of C. platensis (Figs 19-22). One of the shells from Rio Grande Rise is a younger specimen
(Figs 25, 26), but the largest one (Figs 23, 24) presents similar dimensions with the holotype (Tab. I).

The present species is closely related to Cadulus tumidosus Jeffreys, 1877 (Figs 28-35), from eastern Atlantic, regarding shell morphology. HENDERSON (1920) recognized these similarities and the shape variation at the equator in both of them, but preferred to separate the western Atlantic specimens introducing a new name. HENDERSON (1920) described $C$. platensis with a somewhat larger shell than $C$. tumidosus, but the dimensions are very similar. We add that C. platensis can be distinguished by the slowly reduction of the diameter of the shell towards the dorsal aperture (Figs $19,23,25,27)$, while this reduction is more abrupt in $C$. tumidosus (Figs 28, 30, 32, 34).

Cadulus victori sp. nov. Souza, Caetano \& Scarabino urn:lsid:zoobank.org:act:F1CFE103-905A-4022-AD25F0DD321BE220

(Figs 36-41)

Type material. Holotype (CZUFS SCA-00005, shell). Paratype: BRAZIL, Bahia, Camamu-Almada Basin, 1419'48”S 38³2’39”W, 2200 m, coll. 2011 (MNRJ 34466†, 1 shell).

Type locality. BRAZIL, Alagoas, MARSEAL SED 4 sta. AN8, 10²1'22”S 3553'36”W, 400 m, coll. R/V Seward Johnson, 08/x/2013.

Description. Shell up to $4.97 \mathrm{~mm}$ long, $2.09 \mathrm{~mm}$ wide, strongly swollen, maximum diameter at equator; whitish, glossy. In lateral view, convexity is abrupt at both sides, markedly at posterior side; rapidly tapering towards the apertures. In anterior view, convexity more uniform at both sides, biconic. Oval in section. Dorsal aperture simple, compressed anteroposteriorly, slightly wider than long. Ventral aperture simple, wide, compressed anteroposteriorly, slightly wider than long. Measurements: see Tab.I.

Distribution. Brazil: Alagoas, Bahia. Empty shells from 400 to $2200 \mathrm{~m}$.

Etymology. This species is named in honor of Dr. Victor Scarabino for his significant contribution to the systematics of Scaphopoda.

Remarks. The holotype (CZUFS SCA-00005) (Figs $36,37)$ of this newly described species is safely preserved, but the paratype (MNRJ 34466) (Figs 38-41) was destroyed due to the fire at "Museu Nacional". A detailed analysis of the shell morphology was conducted prior to the destruction of the specimen.

Cadulus victori $\mathrm{sp}$. nov. is very inflated at the equator, having a strongly convex outline and a relatively bigger size (Figs 36-40) than other Cadulus from the Atlantic. Cadulus tumidosus (Figs 28-35) is the most similar species. STEINER $\&$ KАВАТ (2004) reported the occurrence of the latter species in Brazil, but there is no confirmed record of this species in this country (Souza et al., 2013). Cadulus victori sp. nov. differs from $C$. tumidosus mainly by the less constricted apical region, the outline from the equator to the dorsal aperture is more sloping in the former (Figs 36-40), while it is straighter in the latter (Figs 28-35). Additionally, even 
the most swollen syntypes of C. tumidosus (Figs 28, 29, 32, 33) do not have such a convex outline like in C. victori sp. nov. (Figs 36-40) that reaches a greater width $(2.1$ vs. 1.9 $\mathrm{mm})$ in shells of smaller length (5.0 vs. $5.5 \mathrm{~mm})$ (Tab. I).

Cadulus victori sp. nov. also resembles Cadulus exiguus Watson, 1879 (Figs 42-44), from deep waters of the Caribbean, Cadulus gibbus Jeffreys, 1883 (Figs 45-48), from the Northeast Atlantic, and Cadulus rossoi Nicklés, 1979, from Senegal, because all have an inflated shell. However, C. victori sp. nov. differs by the much broader dimensions than these species (Tab. I).
Cadulus victori $\mathrm{sp}$. nov. differs from C. platensis (Figs 19-27), and from Cadulus jeffreysi (Monterosato, 1875) (see ApPOLlONi et al., 2018: fig. 40P, for the illustration of the type material) by being more inflated, strongly increasing in diameter towards the equator.

Cadulus victori sp. nov. differs from Cadulus attenuatus Monterosato, 1875 (see APPOLLONI et al., 2018: fig. $40 \mathrm{~N}$, for the illustration of the type material), from the Mediterranean, by being more tapered and with a smooth apex, while $C$. attenuatus has an almost cylindrical shape and a coronated apex.

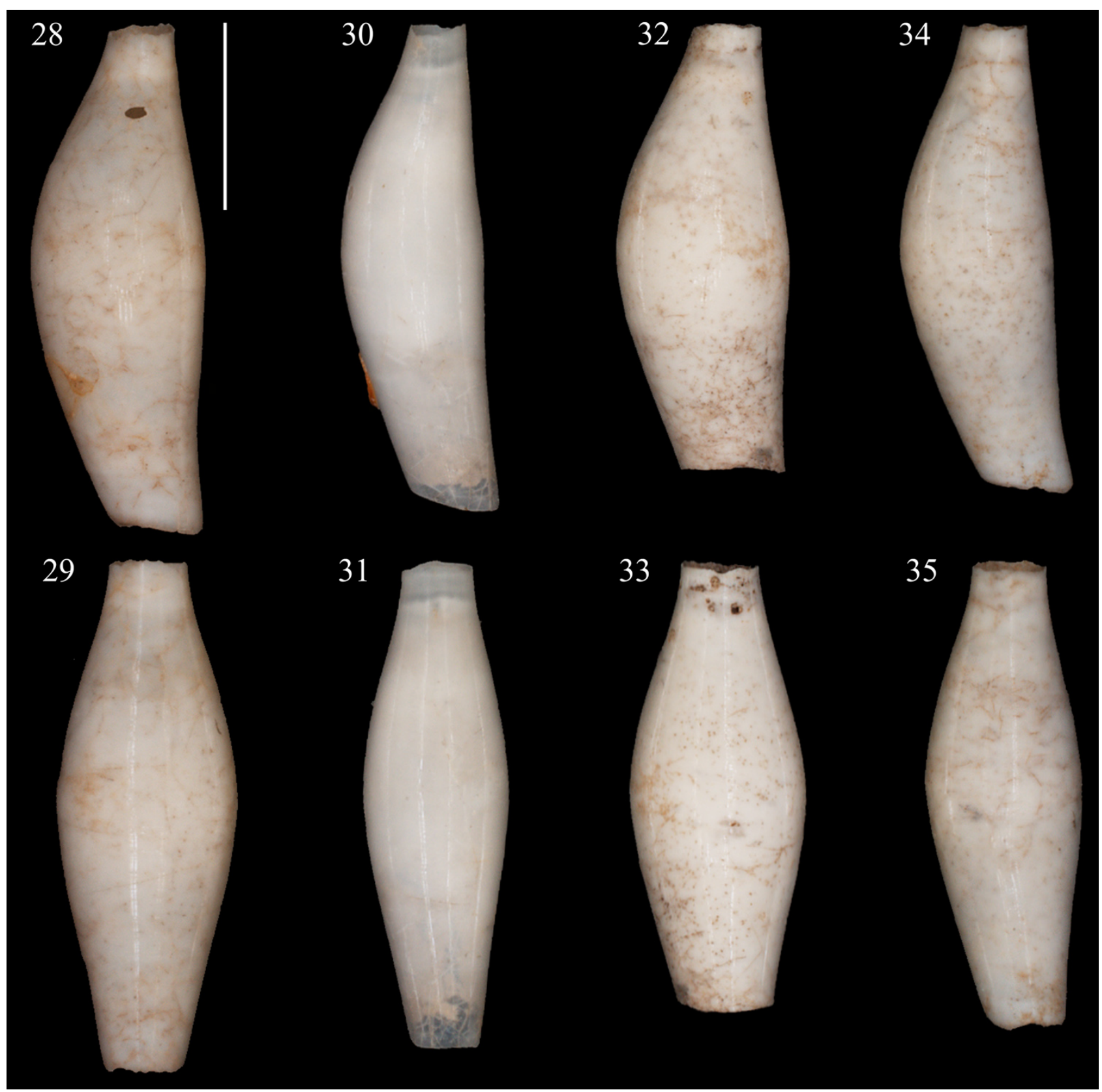

Figs 28-35. Cadulus tumidosus Jeffreys, 1877: syntypes (USNM 169502): 28, 29, same shell; 30, 31, same shell; 32, 33, same shell; 34, 35, same shell. 28, 30, 32, 34, entire shell, lateral view. 29, 31,33, 35, entire shell, anterior view. Scale bar: $2 \mathrm{~mm}$ (all images at same scale). 


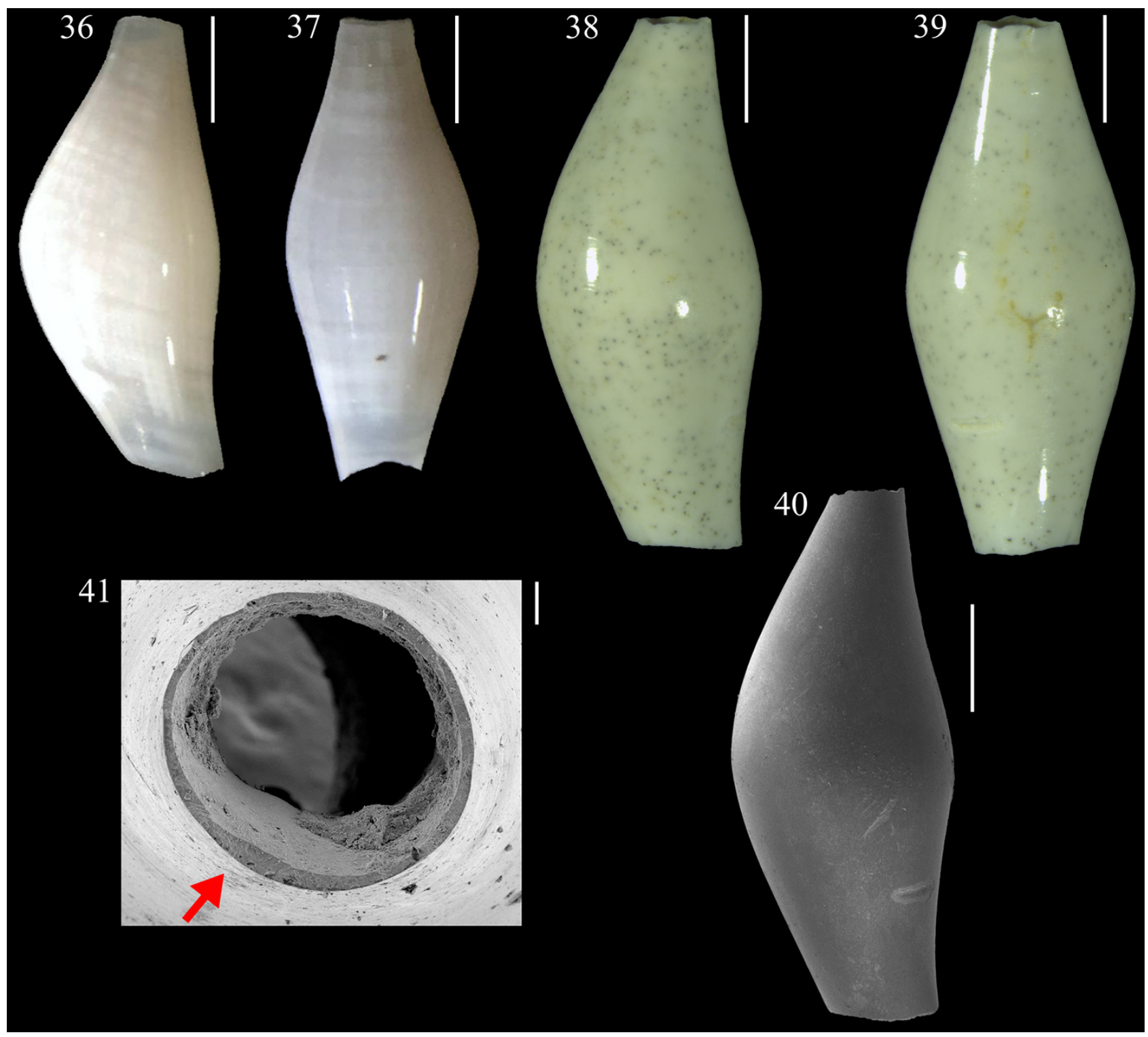

Figs 36-41. Cadulus victori sp. nov. 36, 37, holotype (CZUFS SCA-00005); 38-41, paratype (MNRJ 34466). 36, 38, 40, entire shell, lateral view; 37, 39 , entire shell, anterior view; 41 , detail of dorsal aperture; the arrow indicates the anterior region of the shell. Scale bars: $36-40=1 \mathrm{~mm} ; 41=0.1 \mathrm{~mm}$.

Cadulus victori sp. nov. differs from Cadulus obesus Watson, 1879 by having a more inflated equator and bigger dimensions based on WATSON's (1886:pl. 3, fig. 8 ) illustrations. The four syntypes of $C$. obesus (NHMUK 1887.2.9.84-87) (Fig. 49) are severely damaged by Byne's disease (STEINER \& KABAT, 2004), and the original description is not useful as most Cadulus are similar. Thus, we consider C. obesus as a nomen dubium.

Cadulus victori sp. nov. differs from Cadulus cucurbitus Dall, 1881 (see Henderson, 1920: pl. 20 fig. 1 , for the illustration of the holotype), from Caribbean, by having a more inflated and more convex equator, a smaller proportion between the total length and maximum width (2.3-2.4 vs. 3.2) (Tab. I).

\section{DISCUSSION}

The present work reinforces that although recent taxonomic revisions have been performed on the Scaphopoda from the southwestern Atlantic, there are still unknown or unrecorded species in museum collections (Fig. 50), mostly from poorly sampled areas, especially in the deep sea. The abyssal $(>2,000 \mathrm{~m})$ fauna of the South Atlantic is poorly sampled and is an exciting field to explore the diversity of Scaphopoda. Currently, the deep-sea fauna requires more attention than ever in areas of interest for mining exploration, as is the case of the Rio Grande Rise (MontSERRAT et al., 2019) where $C$. platensis was collected. 


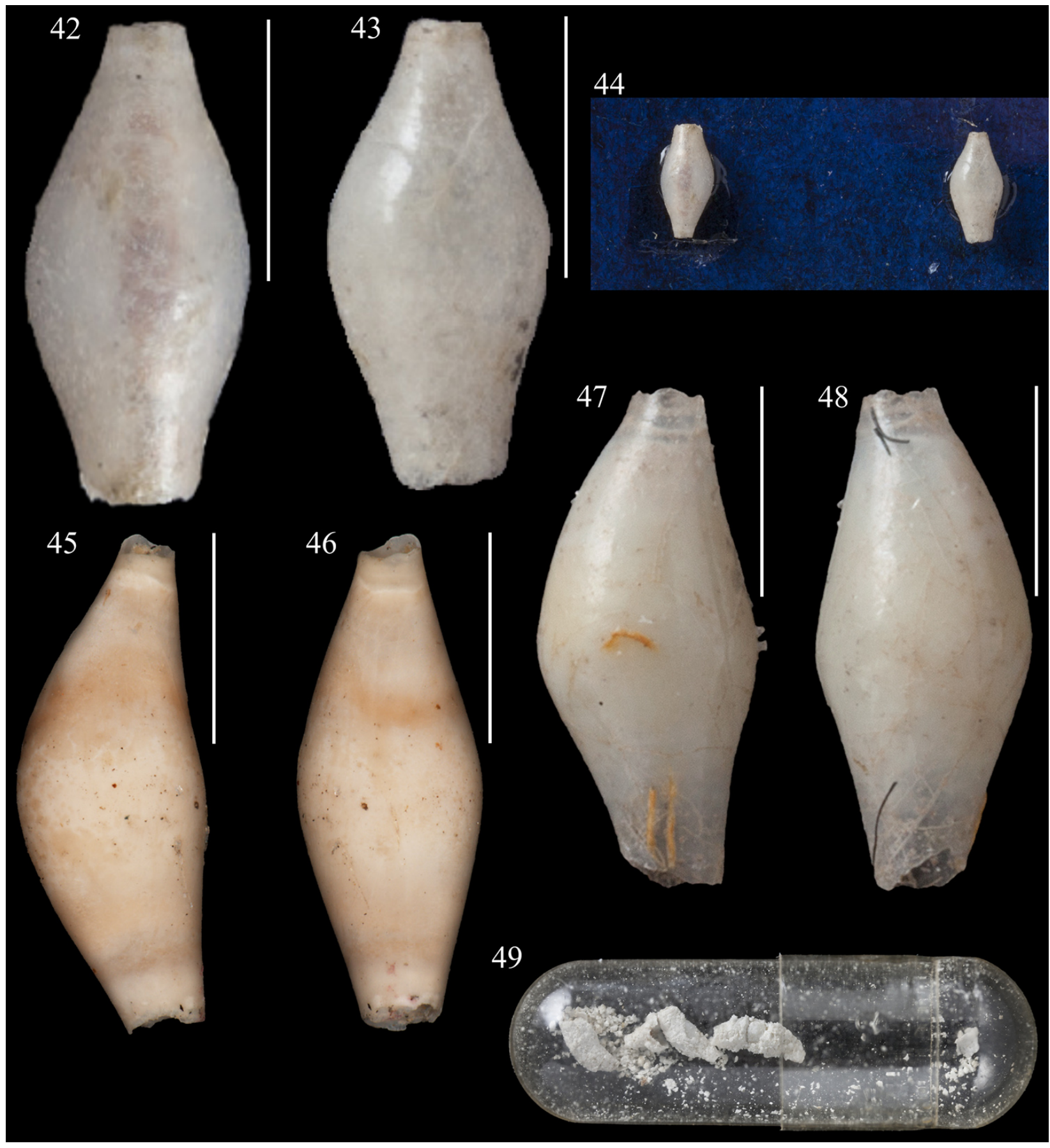

Figs 42-49. Cadulus species. 42-44, Cadulus exiguus Watson, 1879: syntypes, NHMUK 1887.2.9.94, both glued to a cardboard. 45-48, Cadulus gibbus Jeffreys, 1883: 45, 46, syntype (USNM 172858); 47, 48, syntype (NHMUK 1885.11.5.1287); 49, Cadulus obesus Watson, 1879: syntypes (NHMUK 1887.2.9.84-87, 4 shells), all inside a gelatin capsule.

Another situation that masks the real diversity of Scaphopoda is the scarcity of researchers studying the alpha-taxonomy of these mollusks worldwide. In the last decades, the knowledge about phylogenetics, comparative anatomy, ecology and development of Scaphopoda has grown tremendously (e.g., Steiner \& Dreyer, 2003; SimOne, 2009; FALLER et al., 2012; SUMNER-RoONEY et al., 2015; SMith \& SPENCER, 2016; Dantas et al., 2017; SigWART et al., 2017; ViLELA et al., 2019), which is excellent but little attention has been given to regional taxonomic revisions.
Victor Scarabino, an expert on the systematics of Scaphopoda and now retired, has insisted through personal communication about the existence of many undescribed species in museum shelves; several of these are even already named in his notes. Furthermore, it has already been established the need for revisions at several levels in Scaphopoda (SCARABINO, 2008; SCARABINO \& SCARABINO, 2011). Therefore, the continuation of these studies would be critical not only to discover new species, but to review the systematics and our knowledge of the diversity of scaphopods. 


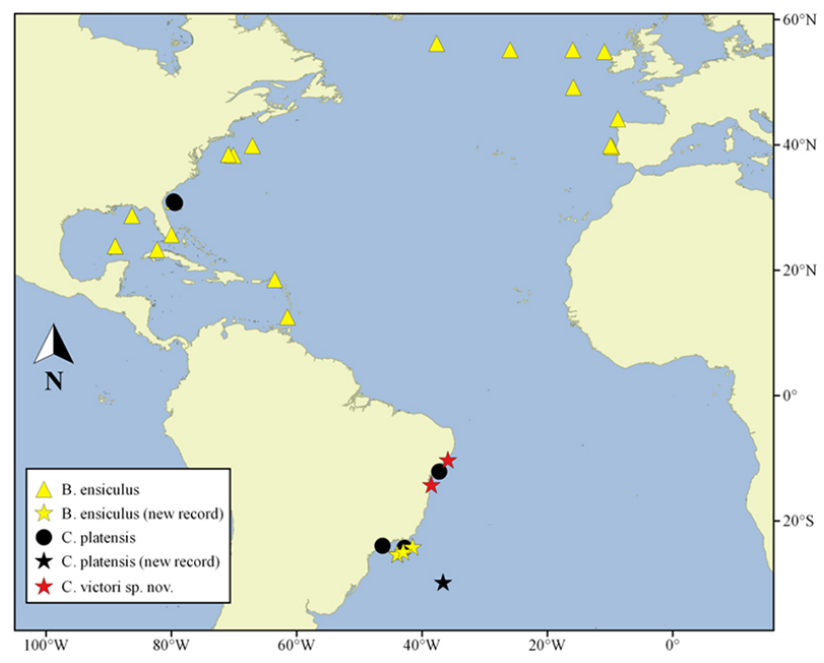

Fig. 50. Confirmed records of the species studied at the Atlantic Ocean: Bathoxiphus ensiculus (yellow symbols), Cadulus platensis (black symbols) and Cadulus victori sp. nov. (red symbols). Stars represents the new records of the present study.

Acknowledgements. We are grateful to Alexandre D. Pimenta (MNRJ), Luiz R. L. Simone (MZSP), Carmen R. P. Guimarães (UFS), Ellen Strong and Yolanda Villacampa (USNM) for access to the collections. Tom White and the photographic unit (NHMUK) for some of the images of type material. Ivan Nekhaev (Saint-Petersburg State University) for helpful translations of Russian texts. PETROBRAS/CENPES and CPRM for collecting samples (MARSEAL and PROERG projects, respectively). A special thanks to Victor Scarabino for his legacy and kind entrustment to pursue his work. Thanks also go to the referees and the Editor-in-chief, Luciano A. Moura, for the contributions to the present work.

\section{REFERENCES}

Аввотт, R. T. 1974. American seashells. The marine Mollusca of the Atlantic and Pacific coasts of North America. New York, Van Nostrand Reinhold Company. 663p.

Absalão, R. S. \& de Paula, T. S. 2004. Shell morphometrics of three species of gadilid Scaphopoda (Mollusca) from the Southwestern Atlantic Ocean: comparing thediscriminating power of primary and secondary descriptors. Zootaxa 706:1-12.

Appolloni, M.; Smriglio, C.; Amati, B.; Lugliè, L.; Nofroni, I.; Tringali, L. P.; Mariottini, P. \& Oliverio, M. 2018. Catalogue of the primary types of marine molluscan taxa described by Tommaso Allery Di Maria, Marquis of Monterosato, deposited in the Museo Civico di Zoologia, Roma. Zootaxa 4477(1):1-138.

Boissevain, M. 1906.The Scaphopoda of the Siboga Expedition, treated together with the known Indo-Pacific Scaphopoda. Uitkomsten op Zoologisch, Botanisch, Oceanographischen Geologisch Gebiedverzameld in Nederlandsch Oost-Indië 1899-1900 a anboord H.M. Sibogaonder commando van Luitenantter zee 1e. kl. G. F. Tydeman 54(Livraison 32): 1-76, pls 1-6.

Caetano, C. H. S. \& Absalão, R. S. 2005. A new species of the genus Polyschides Pilsbry \& Sharp, 1898 (Mollusca, Scaphopoda, Gadilidae) from Brazilian waters. Zootaxa 871:1-10.

Caetano, C. H. S. \& Santos, F. N. 2010. Mollusca, Scaphopoda, Gadilidae, Striocadulus magdalensis Gracia and Ardila, 2009: First record of the genus and species from Brazil. Check List 6(4):687-689.

Caetano, C. H. S. \& Scarabino, V. 2009. Class Scaphopoda Bronn, 1862. In: Rios, E. C. ed. Compendium of Brazilian Sea Shells. Rio Grande, Evangraf, p. 444-457.

Caetano, C. H. S.; Garcia, N. \& Lodeiros, C. J. M. 2007. First record of Paradentalium infractum (Odhner, 1931) (Mollusca, Scaphopoda, Dentaliidae) from the east coast of Venezuela. Brazilian Journal of Biology 67(4):797-798.
Caetano, C. H. S.; Scarabino, V. \& Absalão, R. S. 2006. Scaphopoda (Mollusca) from the Brazilian continental shelf and upper slope $\left(13^{\circ}\right.$ to $21^{\circ} \mathrm{S}$ ) with descriptions of two new species of the genus Cadulus Philippi, 1844. Zootaxa 1267:1-47.

Caetano, C. H. S.; SCarabino, V. \& Absalão, R. S.2010. Brazilian species of Gadila (Mollusca: Scaphopoda: Gadilidae): rediscovery of Gadila elongata comb. nov. and shell morphometrics. Zoologia 27(2):305-308.

CAProtti, E. 2015. Antalis ariannae, uma nuova specie mediterranea. Malacologia Mostra Mondiale 89:3-5.

Chistikov, S. D. 1983. [Modern molluses of the family Entalinidae (Scaphopoda Gadilida), 4, subfamily Bathoxiphinae]. Zoologichesky Zhurnal 62(2):181-190. [originally in Russian].

DALL, W. H. 1881. Reports on the results of dredging, under the supervision of Alexander Agassiz, in the Gulf of Mexico and in the Caribbean Sea (1877-78), by the United States Coast Survey Steamer "Blake", Lieutenant-Commander C.D. Sigsbee, U.S.N., and Commander J. R. Bartlett, U. S. N., commanding. XV. Preliminary report on the Mollusca. Bulletin of the Museum of Comparative Zoology 9(2):33-144.

DALL, W. H. 1889. Reports on the results of dredging, under the supervision of Alexander Agassiz, in the Gulf of Mexico (1877-78) and in the Caribbean Sea (1879-80), by the U. S. Coast Survey steamer "Blake", Lieut.-Commander C. D. Sigsbee, U. S. N., and Commander J. R. Bartlett, U. S. N., Commanding. XXIX-Report on the Mollusca. Part II. Gastropoda andScaphopoda. Bulletin of the Museum of Comparative Zoology 18:1-492.

DALL, W. H. 1890. Contributions to the Tertiary fauna of Florida, with especial reference to the Miocene silex-beds of Tampa and the Pliocene beds of the Caloosahatchie River. Part I. Pulmonate, opisthobranchiate and orthodont gastropods. Transactions of the Wagner Free Institute of Science of Philadelphia 3:1-200.

DALL, W. H. 1927. Small shells from dredgings off the southeast coast of the United States by the United States Fisheries Steamer "Albatross" in 1885 and 1886. Proceedings of the United States National Museum 70:1-134.

Dantas, R. J. S.; Laut, L. L. M. \& Caetano, C. H. S. 2017. Diet of the amphi-Atlantic scaphopod Fissidentalium candidum in the deep waters of Campos Basin, south-eastern Brazil. Journal of Marine Biological Association of the United Kingdom 97(6):1259-1266.

EMERson, W. K. 1952. The scaphopod mollusks collected by the first Johnson-Smithsonian deep-sea expedition. Smithsonian Miscellaneous Collections 117(6): 1-14.

Faller, S.; Rothe, B. H.; Todt, C.; Schmidt-Rhaesa, A. \& Loesel, R. 2012. Comparative neuroanatomy of Caudofoveata, Solenosgastres, Polyplacophora, and Scaphopoda (Mollusca) and its phylogenetic implications. Zoomorphology 131:149-170.

Gofas, S.; Luque, A. A.; Templado, J. \& Salas, C. 2017. A national checklist of marine Mollusca in Spanish waters. Scientia Marina 81(2):241-254.

Henderson, J. B. 1920. A monographof the East American scaphopod mollusks. United States National Museum Bulletin 111:1-177.

JEFFREYS, J. G. 1877. New and peculiar Mollusca of the order Solenoconchia procured during the Valorous expedition. Annals and Magazine of Natural History 4(19):154-158.

JeFFREYS, J. G.1882. On the Mollusca procured during the 'Lightning' and 'Porcupine' Expeditions, 1868-70 (Part V). Proceedings of the Zoological Society of London 1882:656-687.

Lamprell, K. L. \& Healy, J. M. 1998. A revision of the Scaphopoda from Australian waters (Mollusca). Records of the Australian Museum Supplement 24:1-189.

MolluscaBase. 2018a. Entalinidae Chistikov, 1979. Available at $<$ http:// www.molluscabase.org/aphia.php? $\mathrm{p}=$ taxdetails\&id $=13695>$. Accessed on 20 April 2020.

MolluscaBASE. 2018b. Scaphopoda. Available at $<$ http://molluscabase. org/aphia.php?p=taxdetails\&id=104>. Accessed on 20 April 2020.

Montserrat, F.; Guilhon, M.; Corrêa, P. V. F.; Bergo, N. M.; Signori, C. N.; Tura, P. M.; Maly, M. S.; Moura, D.; Jovane, L.; Pellizari, V.; Sumida, P. Y. G.; Brandini, F. P. \& Turra, A. 2019. Deep-sea mining on the Rio Grande Rise (Southwestern Atlantic): A review on environmental baseline, ecosystem services and potential impacts. Deep-Sea Research Part I, 145:31-58. 
NiCKLÈs, M. 1979. Scaphopodes de 1'Ouest-Africain (Mollusqua, Scaphopoda). Bulletin du Muséum national d'Histoire naturelle, section A, Zoologie, Biologie et Écologieanimales (4'serie) 1:41-77.

Pilsbry, H. A. \& Sharp, B. 1897-1898. Scaphopoda. In: Tryon, G. W. ed. Manual of Conchology, 17. Philadelphia, Conchological Section, Academy of Natural Sciences. 280p. (1897: 1-144 p., 26 pls.; 1898: i-xxxii+145-280 p., pls.27-37).

QuinN, J. F. 1979. Biological results of the University of Miami deep-sea expeditions. 130. The systematics and zoogeography of the gastropod family Trochidae collected in the straits of Florida and its approaches. Malacologia 19(1):1-62.

QuinN, J. F. 1983. Carenzia, a new genus of Seguenziacea (Gastropoda: Prosobranchia) with the description of a new species. Proceedings of the Biological Society of Washington 96(3):355-364.

Reynolds, P. D. 2002. The Scaphopoda. Advances in Marine Biology 42:137-236.

Rıos, E. C. 1994. Seashells of Brazil. 2ed. Rio Grande, Editora Fundação Universidade Rio Grande. 368p.

Rosenberg, G. 2014. A new critical estimate of named species-level diversity of the Recent Mollusca. American Malacological Bulletin 32(2):308-322. http://dx.doi.org/10.4003/006.032.0204

Sahlmann, B. \& van Der Beek, J. 2016. A new scaphopod, Dentalium humboldti n. sp., from the Concepción Methane Seep off Chile (Mollusca: Scaphopoda). SchriftenzurMalakozoologie 29:41-48.

Sahlmann, B. \& Wiese, V. 2016. A new scaphopod from Yemenite waters, Tesseracme arabica n. sp. (Mollusca: Scaphopoda). SchriftenzurMalakozoologie 29:33-40.

Sahlmann, B.; van Der BeeK, J. \& Wiese, V. 2016. Fissidentalium (Compressidentalium) pseudohungerfordi n. sp., a well known undescribed scaphopod in the group of Fissidentalium (Compressidentalium) hungerfordi (Pilsbry\& Sharp 1897) (Mollusca: Scaphopoda). SchriftenzurMalakozoologie 29:19-32.

Salvador, R. B.; Cavallari, D. C.\& Simone, L. R. 2014. Seguenziidae (Gastropoda: Vetigastropoda) from SE Brazil collected by the Marion Dufresne (MD55) expedition. Zootaxa 3878(6):536-550.

SCARABINO, F. 2003. Lista sistemática de los Aplacophora, Polyplacophora y Scaphopoda de Uruguay. Comunicaciones de la Sociedad Malacológica del Uruguay 8(78-79):191-196.

Scarabino, V. 1970. Las espécies del genero Cadulus Philippi, 1844 (Moll. Scaphopoda) em el Atlantico Sudoccidental (Lat. $24^{\circ} \mathrm{S}$ a $\left.38^{\circ} \mathrm{S}\right)$. Comunicaciones de la Sociedad Malacológica del Uruguay 3(19):39-48.

Scarabino, V. 1975. Class Scaphopoda. In: Rios, E. C. ed. Brazilian marine mollusks iconography. Rio Grande, Museu Oceanográfico do Rio Grande, p. 180-186.

Scarabino, V. 1985. Class Scaphopoda Bronn, 1862. In: Rios, E. C. ed. Seashells of Brazil. Rio Grande, Museu Oceanográfico do Rio Grande, p. 196-202.

Scarabino, V. 1986a. Nuevos taxa abisales de la clase Scaphopoda (Mollusca). Comunicaciones Zoologicas del Museo de Historia Natural de Montevideo 11(155):2-19.

SCARABINo, V. 1986b. Systematics of Scaphopoda, I. Three new bathyal and abyssal taxa of the order Gadilida from South and North Atlantic ocean. Comunicaciones Zoológicas del Museo de Historia Natural de Montevideo 11(161):1-15.

SCarabino, V. 1994. Class Scaphopoda Bronn, 1862. In: Rios, E. C. ed. Seashells of Brazil. 2ed. Rio Grande, FURG, p. 305-310.

SCarabino, V. 1995. Scaphopoda of the tropical Pacific and Indian waters, with descriptions of 3 new genera and 42 new species. In: Bouchet, P. ed. Résultats des Campagnes Musorstom, v.14. Mémoires du Muséum national d'Histoire naturelle 167:189-379.

SCARABino, V. 2008. New species and new records of scaphopods from New Caledonia. In: Héros, V.; Cowie, R. H. \& Bouchet, P. eds. Tropical Deep-Sea Benthos 25.Paris, Mémoires du Muséum national d'Histoire naturelle 196:215-268.

Scarabino, V. \& CaEtano, C. H. S. 2008. On the genus Heteroschismoides Ludbrook, 1960 (Scaphopoda: Gadilida: Entalinidae), with descriptions of two new species. The Nautilus 122(3):171-177.
Scarabino, V.; Caetano, C. H. S. \& Carranza, A. 2011. Three new species of the deep-water genus Bathycadulus (Mollusca, Scaphopoda, Gadilidae). Zootaxa 3096:59-63.

Scarabino, V. \& Scarabino, F. 2010. A new genus and thirteen new species of Scaphopoda (Mollusca) from the tropical Pacific Ocean. Zoosystema 32(3):409-423.

SCARABino, V. \& SCARABINO, F. 2011. Ten new bathyal and abyssal species of Scaphopoda from the Atlantic Ocean. The Nautilus 125(3):127-136.

Sigwart, J. D.; Sumner-Rooney, L. H.; Dickey, J. \& CARey, N. 2017. The scaphopod foot is ventral: more evidence from the anatomy of Rhabdus rectius (Carpenter, 1864) (Dentaliida: Rhabdidae). Molluscan Research 37(2):79-87.

Silva-Filho, G. F. S.; Pinto, S. L. \& Alves, M. S. 2010. Two new speciesof the genus Gadila Gray, 1847 (Mollusca, Scaphopoda, Gadilidae) from Brazilian coast. Revista Nordestina de Zoologia 4(1):48-53.

Silva-Filho, G. F. S.; Tenório, D. O.; Pinto, S. L. \& Alves, M. S. 2012. Mollusca Scaphopoda Bronn, 1862 da Costa Nordeste do Brasil. Tropical Oceanography 40(1):29-103.

Silva-Filho, G. F. S.; Tenório, D. O.; Pinto, S. L. \& Alves, M. S. 2016. Scaphopoda (Mollusca) of Fernando de Noronha - Pernambuco and Atol das Rocas - Rio Grande do Norte, Brazil. Revista Nordestina de Zoologia 10(2):52-73.

SimONE, L. R. L. 2009. Comparative morphology among representatives of main taxa of Scaphopoda and basal protobranch Bivalvia (Mollusca). Papéis Avulsos de Zoologia 49(32):405-457.

Smith, A. M. \& Spencer, H. G. 2016. Skeletal mineralogy of scaphopods: an unusual uniformity. Journal of Molluscan Studies 82(2):344-348.

Souza, L. S.; AraúJo, I. C. V. \& CaETano, C. H. S. 2013. A commented list of Scaphopoda (Mollusca) found along the Brazilian coast, with two new synonymies in the genus Gadila Gray, 1847. Biota Neotropica 13(2):228-235.

Steiner, G. \& Dreyer, H. 2003. Molecular phylogeny of Scaphopoda (Mollusca) inferred from 18S rDNA sequences: support for a Scaphopoda-Cephalopoda clade. Zoologica Scripta 32(4):343-356.

Steiner, G. \& Kabat, A. R. 2001. Catalogue of supraspecific taxa of Scaphopoda (Mollusca). Zoosystema 23(3):433-460.

Steiner, G. \& Kabat, A. R. 2004. Catalog of species-group names of Recent and fossil Scaphopoda (Mollusca). Zoosystema 26(4):549-726.

Sumner-Rooney, L. H.; SChröDL, M.; Lodde-Bensch, E.; LindBerg, D. R.; Hess, M.; Brennan, G. P. \& Sigwart, J. D. 2015. A neurophylogenetic approach provides new insight to the evolution of Scaphopoda. Evolution \& Development 17(6):337-346.

TownSEND, C. H. 1901. Dredging and other records of the United States Fish Commission Steamer Albatross, with bibliography relative to the work of the vessel. United States Fish Commission Report for 1900 1:387-562.

VerriLl, A. E. 1885. Third catalogue of Mollusca recently added to the fauna of the New England coast and the adjacent parts of the Atlantic, consisting mostly of deep-sea species, with notes on others previously recorded. Transactions of the Connecticut Academy of Arts and Sciences 6:395-452.

Vilela, P. M. S.; Souza, L. S. \& CaEtano, C. H. S. 2019. Larval and early post-larval shell of three deep-sea Scaphopoda (Mollusca) from the southwest Atlantic. Molluscan Research 39(1):35-43.

WARÉN, A. 1980. Marine Mollusca described by John Gwyn Jeffreys, with the location of the type material. Conchological Society of Great Britain and Ireland Special Publication 1:1-60.

WarÉN, A. 1991. New and little known Mollusca from Iceland and Scandinavia. Sarsia 76:53-124.

WATSON, R. B. 1886. Report on the Scaphopoda and Gasteropoda collected by H.M.S. Challenger during the years 1873-1876. Report on the Scientific Results of the Voyage of H.M.S. Challenger, Zoology 15(2): 1-680, 692-756.

Zamudio, K. R.; Kellner, A.; Serejo, C.; Britto, M. R.; Castro, C. B.; BuckuP, P. A.; Pires, D. O.; Couri, M.; KurY, A. B.; CARDOSO, I. A.; Monné, M. L.; Pombal Jr., J.; Patiu, C. M.; Padula, V.; Pimenta, A.D.; Ventura, C. R. R.; Hajdu, E.; Zanol, J.; Bruna, E. M.; FitZPATRick, J. \& Rocha, L.A. 2018. Lack of Science support fails Brazil. Science 361(6409):1322-1323. 